\title{
Management of water resources in India
}

\begin{abstract}
India with an area of $3287263 \mathrm{~km}^{2}$ is the seventh largest country in the world and by population it ranks at number two after China. About $17 \%$ of the world population lives in India and it has achieved all- round socio-economic progress since independence. In recent decades due to the tremendous increase in the human population in India from 361 million in 1951 to 1210 million in 2011; the per capita availability of fresh water in the country has come down from $6371 \mathrm{~m}^{3}$ a year to $1902 \mathrm{~m}^{3}$ a year that is by 70 percent. This paper provides an overview of freshwater availability from rainfall in India as also in its different states under the impact of the population growth. Of the 28 states, the availability of fresh water per capita in the four contiguous states of Haryana, Uttar Pradesh, Bihar and West Benga has been estimated to be less than $1000 \mathrm{~m}^{3}$ a year. These four states are water stressed which may experience severe water supply instability. The solution to heal the water scarcity problem in these four states lies in the adaptation of an efficient and integrated policy for water use and application of relevant water conservation techniques.
\end{abstract}

Volume 3 Issue 5 - 2019

\author{
Rakhecha PR \\ Independent researcher: D- 82, Shastrinagar, Formerly at: Indian \\ Institute of Tropical Meteorology, Pune, India
}

Correspondence: Rakhecha PR, Independent researcher: D-82, Shastrinagar, Jodhpur-342003, Indian Institute of Tropical Meteorology, Pune, India, Email rakhechapukhraj@gmail.com

Received: August 16,2019 | Published: September 18, 2019

Keywords: monsoon, rainwater, water quality, groundwater, surface water

\section{Introduction}

Water is considered absolutely essential for sustaining all forms of life (human, animal and plant). Also, it is one of the most important components which influence economic, agricultural and industrial growth of mankind. However, most nations of the world are facing acute and growing water shortages due to the tremendous increase in the human population over the last few decades. Also increasing urbanization and industrialization are multiplying the problems of pollution and deterioration of quality of water. Environmentalists say that the next wars to be fought are not going to be about land but water. In these water scarcity times, in India, as in many other parts of the world the issue of decreasing availability of water and its management is a subject of concern and for a serious study. The annual renewable water resources per capita in India was about $6372 \mathrm{~m}^{3}$ in 1951 which fell to $1902 \mathrm{~m}^{3}$ in 2011 because of an increase in human population by a factor 3.4 over the past 60 years. ${ }^{1}$ The population study has inferred that India's human population will be between 1.5 and 1.8 billion by $2050^{2}$ and per capita water availability will fall to $1400 \mathrm{~m}^{3}$ per year making India a water stressed country. Apparently, changes in water quantity and quality are occurring mainly as consequences of changes in human population including environmental factors. These changes may lead to water supply instability to different sectors: domestic use, agriculture, industry, hydropower generation and the aquatic environment. For this problem there is a need for more detailed and updated science based knowledge regarding the quantity and quality of water availability from the monsoon rains in various states of India, population trend, water use and water conservation. This paper throws up some vital data on water and population of India which should be useful to improve sustainable water management practices. India with a total area of $3287263 \mathrm{~km}^{2}$ is the seventh largest country in the world and by population it ranks at number two after China. ${ }^{3}$ India has achieved all-round socio- economic progress as also self-sufficiency in food grains production since independence in 1947.

\section{Climate systems}

The climate of India is characterized by distinct seasonality. During the course of a year, seasons come and go one after the other with surprising precision. India Meteorological department (IMD) has recognized the four distinct seasons: (i) the cold weather season or winter (January to February), (ii) the hot weather season or summer season (March to May), (iii) the southwest monsoon season or Rainy season (June to September) and (iv) the cool season or the postmonsoon season (October to December). The cold weather season is characterized by clear sky, pleasant weather, low temperatures varying from $10-15^{\circ} \mathrm{C}$ in the northern areas to around $20-25^{\circ} \mathrm{C}$ in the southern parts, low humidity, high range of temperature, cool and slow northern winds. ${ }^{4}$ The hot weather season commences in March and continues till June. High temperatures averaging around $30-40^{\circ} \mathrm{C}$ and low humidity are the chief characteristics of this season. The rainy season in India starts with the onset of the southwest monsoon in June and continues till the end of September. High heat, high humidity, extensive clouding and several spells of moderate to heavy rain with strong surface winds are the main characteristics of this season. From time to time cyclonic storms from the Bay of Bengal and the Arabian Sea move across the country and bring heavy rainfall and floods in the Indian rivers. About 76 per cent of the total annual rainfall occurs between June and September. ${ }^{5,6}$ The cool season or the post monsoon season starts with the beginning of the withdrawal of the southwest monsoon in the end of September and continues up to December after which the winter season starts. Water resource refers generally to that part of fresh water which is renewable annually and includes surface water, soil water and underground water, with atmospheric precipitation as their main source. Obviously, the determination of surface and underground water resources first demands to know the amount of water that is received from rainfall in each state of India and in India as a whole. 


\section{India's rainwater resources availability}

Rainfalls during the southwest and northeast monsoons bring freshwater In India. Obviously, rainfall measurements are vital for the assessment of water availability studies. Rainfall measurement in India was started towards the end of the $18^{\text {th }}$ century. The first recorded data were obtained at Calcutta (now Kolkata) in 1784 followed by observations at Madras (now Chennai) from 1792, Bombay (now Mumbai) from 1823 and Simla from 1840. However, the recording of rainfall at a large number of stations was started from the middle of the $19^{\text {th }}$ century. There were about 3000rainfall observational stations in India in 1947 and their data are available for more than 100 years. ${ }^{7}$ The need for increasing the networks of rainfall sites for the agriculture and water development works was felt after 1947 and as a result more rain gauges were installed throughout the country. At present there are about 5000 rainfall observational stations in India and their daily rainfall data are available in digital form with the India Meteorological Department (IMD).

The amount of rainfall over various stations, regions and river basins gives the quantity of water available naturally. The mean annual rainwater distribution over the country is shown in Figure 1 and the annual average rainwater received by different states of India is given in Table 1. This Figure shows that rainfall is unequally distributed throughout the country. The highest annual rainfall of $200 \mathrm{~cm}$ or more occurs over the west coast and also over north Bengal, Meghalaya hills and Assam. Along the iconic Western Ghats there are places whose average annual rainfall is of the order of $600 \mathrm{~cm}$ and within 80 to $100 \mathrm{~km}$ to the east of these Ghats, rainfall decreases rapidly to about 50 to $60 \mathrm{~cm}$. From the Orissa coast to west Rajasthan the average annual rainwater amount progressively decreases from $150 \mathrm{~cm}$ to $20 \mathrm{~cm}$ and it is even less in the deserts of western Rajasthan.

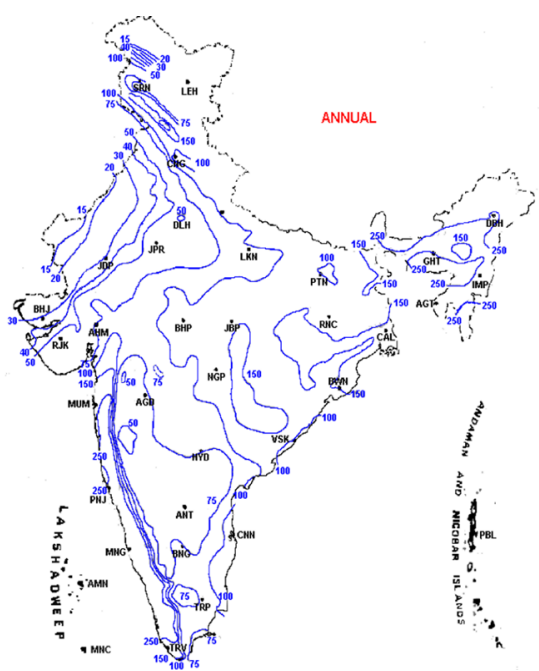

Figure I Annual rainfall (cm) distribution over India. ${ }^{10}$

Table I Mean monthly and annual rainfall (I90I to 1960) of all India \& coefficient variability (CV)

\begin{tabular}{llllll}
\hline Months & $\begin{array}{l}\text { Mean rainfall } \\
(\mathbf{c m})\end{array}$ & \%of annual & $\mathbf{C V}(\%)$ & $\begin{array}{l}\text { Highest rainfall } \\
(\mathbf{c m})\end{array}$ & Lowest rainfall $(\mathbf{c m})$ \\
\hline January & 1.1 & 0.9 & 100 & 5.3 & 0.4 \\
February & 1.7 & 1.7 & 77 & 5.1 & 0.3 \\
March & 2.5 & 2.1 & 44 & 5.7 & 0.7 \\
April & 3.8 & 3.2 & 24 & 6.9 & 1.8 \\
May & 6.3 & 5.4 & 25 & 10.3 & 3.4 \\
June & 16.6 & 14.1 & 21 & 22.5 & 9.7 \\
July & 29.7 & 25.3 & 13 & 35.9 & 17.1 \\
August & 26.0 & 22.3 & 14 & 33.9 & 17.8 \\
September & 17.4 & 14.8 & 22 & 27.1 & 10.3 \\
October & 7.8 & 6.7 & 39 & 16.0 & 2.1 \\
November & 3.1 & 2.6 & 55 & 7.5 & 0.3 \\
December & 1.4 & 1.2 & 57 & 3.7 & 0.1 \\
Annual & 117.4 & 100 & 10 & $135(1917)$ & $81(1918)$ \\
\hline
\end{tabular}

Based on rainfall observations of about 3000 stations from 1901 to 1960 , the mean monthly and annual rainfall values for India as a whole estimated by ${ }^{5,6}$ are given in Table 1 . The country receives on an average $117 \mathrm{~cm}$ of rainfall every year which is more in number than elsewhere in the world. But, it is unequally distributed in time and most of it $(76 \%)$ comes in a few months of the monsoon season (JuneSeptember). The Table 1 shows that each of the monsoon months contributes more than 15 per cent of annual rainwater. The $\mathrm{CV}$ of these four months varies from 13 to 22 percent while other months have high variability. The average seasonal rainwater amounts are $2.8,12.6$,
89.7 and $12.3 \mathrm{~cm}$ for winter, summer, southwest monsoon and post monsoon contributing $2.4,10.7,76.4$ and 10.5 per cent respectively to the annual rainwater amount. Parthasarathy et $\mathrm{al},{ }^{7}$ who used more rainfall data for the period 1871 to 1994 revealed that estimates of monthly and annual rainfall values obtained by them for India are not significantly different from those estimated $b^{5,6}$ This indicates that the renewable water resources remained constant if not changing as a result of the widely reported no statistically significant trend of increase or decrease in the Indian rainfall. ${ }^{1}$ 


\section{Variability in annual rainwater availability}

The rainfall is not only unevenly distributed in the seasons, but it also varies considerably from year to year. The frequency distribution of the annual rainwater for the 123year period (1871 to 1993) is given in Table 2. This table shows that there is a considerable variation in rainwater from year to year. For instance, India's average annual rainfall is around $117 \mathrm{~cm}$ but in very dry years the annual rainfall may be reduced to only $80-100 \mathrm{~cm}$, while in extraordinarily wet years it may exceed $125-135 \mathrm{~cm}$. The too less water from low rainfall or too much water from high rainfall has often led to conditions of droughts and floods respectively in India affecting one or the other region. The fresh water resources of an area comprise mainly of (1) surface runoff (rivers, lakes, ponds, etc.) and (2) ground water resources.

\section{Surface runoff and evapo-transpiration}

India has 14 major river basins and form 83 percent of the total drainage area. ${ }^{8}$ The minor and desert river basins cover 17 percent of the total drainage area (Table 3). The Indus River, the Ganga River and the Brahmaputra River are the important Himalayan Rivers in the northern part of India. The main rivers in the central and southern India are the Mahanadi, the Subarnarekha, the Tapi, the Narmada, the Godavari, the Krishna, the Mahi, the Sabarmati, the Cauvery and the Pennar. The country receives a total of $4000 \mathrm{~km}^{3}$ as rainwater (the product of the rainfall $117 \mathrm{~cm}$ and the land area of India $3287263 \mathrm{~km}^{2}$ ). Of this about $1400 \mathrm{~km}^{3}$ of water is lost to the atmosphere by evapotranspiration and $731 \mathrm{~km}^{3}$ water goes into the soil. According to the Ministry of Water Resources, Govt. of India, the remaining $1869 \mathrm{~km}^{3}$ goes as surface runoff through river flow. ${ }^{8,9}$ The surface water potential of about $1869 \mathrm{~km}^{3}$ is dispersed over the rivers in India (Table 3). This shows that roughly $47 \%$ of the annual rainwater is converted into surface runoff. The remaining $53 \%$ is lost through evaporation and transpiration and percolation into the soil. The main characteristics of runoff of these river basins are their uneven regional distribution. ${ }^{10}$

Table 2 Frequency of area average rainwater over India

\begin{tabular}{llll}
\hline Rainfall range $\mathbf{( c m})$ & Frequency & Rainfall $\mathbf{( c m )}$ & Frequency \\
\hline $81-85$ & 2 & $|1|-\mid 15$ & 20 \\
$86-90$ & 2 & $116-120$ & 16 \\
$91-95$ & 5 & $121-125$ & 11 \\
$96-100$ & 16 & $126-130$ & 2 \\
$101-105$ & 18 & $|3|-135$ & 4 \\
$106-110$ & 27 & Total & 123 \\
\hline
\end{tabular}

Table 3 Mean annual surface runoff of the major river basins in India ${ }^{8}$

\begin{tabular}{llll}
\hline River basin & Basin area in $\mathbf{k m}^{\mathbf{2}}$ & Average annual Runoff in $\mathbf{k m}^{\mathbf{3}}$ & \% of total runoff in the basin \\
\hline Indus & 321,290 & 80 & 4.3 \\
Ganga & 861,404 & 550 & 29.4 \\
Brahmaputra & 187,110 & 591 & 31.6 \\
Sabarmati & 21,674 & 4 & 0.2 \\
Mahi & 34,842 & 11 & 0.6 \\
Narmada & 98,796 & 40 & 2.1 \\
Tapi & 65,145 & 20 & 1.1 \\
Subarnarekha & 19,300 & 12 & 0.6 \\
Brahmani & 39,033 & 29 & 1.5 \\
Mahanadi & 141,600 & 116 & 3.6 \\
Godavari & 312,812 & 58 & 6.2 \\
Krishna & 258,948 & 7 & 3.1 \\
Pennar & 55,213 & 19 & 0.4 \\
Cauvery & 87,900 & 265 & 1.0 \\
Minor \& desert rivers & 540,000 & & 14.2 \\
\hline
\end{tabular}

\section{Groundwater potential}

In India groundwater is a major source of water supply. Approximately $731 \mathrm{~km}^{3}$ water that enters the soil, $299 \mathrm{~km}^{3}$ is held as soil moisture and $432 \mathrm{~km}^{3}$ goes as deep seepage that adds to groundwater. ${ }^{11,12}$ Thus the total annual quantum of water available in India (the sum of runoff in its rivers and groundwater recharge) is about $2301 \mathrm{~km}^{3}$. When surface water sources become insufficient due to less rain, population growth etc., men tried to dig wells and this was the exclusive method of obtaining groundwater supply. Historically, digging of wells is considered as the most ancient method of obtaining water supply other than from lakes, rivers etc. Besides India, wells were also constructed in other ancient countries such as Egypt, Greece etc.

\section{Population and water availability in India}

By population India ranks at number two after China. Decadal growth of population and per capita water availability in India from 1901 are shown in Table 4. The per capita availability of water has been steadily diminishing in proportion to the growth of the population. Table shows that India's population has increased by a factor 3.4 over the last 60years (from 1951 to 2011). The population study has inferred that India's human population will be between 1.5 and 1.8billion by $2050^{2}$ and per head water availability will fall to $1400 \mathrm{~m}^{3}$ per year making India a water stressed country. Apparently, changes in water quantity and quality are occurring mainly as consequences of changes in human population including environmental factors. Apparently no goal is more crucial to healing the problem of reduction of water availability than stabilizing the human population. 
Table 4 Population and per capita water availability in India'

\begin{tabular}{llllll}
\hline Year & Population (million) & Water availability $\left(\mathbf{m}^{3} /\right.$ year $)$ & Year & Population $($ million) & Water availability $\left(\mathbf{m}^{3} / \mathbf{y e a r}\right)$ \\
\hline 1901 & 238 & 9652 & 1961 & 439 & 5239 \\
1911 & 252 & 9127 & 1971 & 548 & 4197 \\
1921 & 251 & 9156 & 1981 & 683 & 3368 \\
1931 & 279 & 8247 & 1991 & 847 & 2719 \\
1941 & 319 & 7220 & 2001 & 1029 & 2236 \\
1951 & 361 & 6372 & 2011 & 1210 & 1902
\end{tabular}

Assessment of annual water resources of different states in India

India with an area of $3287263 \mathrm{~km}^{2}$ has 28states and 9union territories. It is important to know how much water from rainfall each state of the country gets on average in a year, and to estimate the total stocks of surface water and groundwater resources for their utilization by user sectors. The updating of the assessment of rainwater resource of different states of India was first done by the India Meteorological department ${ }^{13}$ in 1962. The area average annual rainfalls for each of the 28states and for the country as a whole are listed in Table 5. The main characteristic of rainwater in India is their unequal distribution from one state to another and their averages of annual rainfall range from a high of $300 \mathrm{~cm}$ in Kerala to a low of $55 \mathrm{~cm}$ in Haryana. These rainwater values play an important role for availability of water in the different states.

The rainfall-runoff ratio for the country as a whole is approximately 47 per cent. The average annual rainfalls for each state of the country are listed in Table 5 and therefore by using this ratio, the estimates of annual surface (runoff) water of each state can be easily calculated.

Table 5 Population and water resources of different states in india. ${ }^{3}$
The data on population, the average annual rainfalls, the estimated annual surface water potential, and groundwater potential and the annual water availability per capita for each state of India are listed in Table 5. The data indicates that the disparity among states in per capita water availability is wide. Arunachal Pradesh has the highest value of estimated per capita water availability of about $65071 \mathrm{~m}^{3 /}$ year, and the lowest value of per capita water of about $8315 \mathrm{~m}^{3} /$ year is in Bihar. States or regions are characterized as water stressed or scarce depending on the amount of renewable water available. When the per capita availability of renewable water in a region is less than $17005 \mathrm{~m}^{3}$ a year, it is considered as water stressed region. Whereas if the of water availability is less than $10005 \mathrm{~m}^{3}$ a year the situation is characterized as that of water scarcity. Of the 285 states, the annual availability of fresh water per capita is less than $10005 \mathrm{~m}^{3}$ in the four contiguous states of Haryana, Uttar Pradesh, Bihar and West Bengal. These four states are water scarce and experience a severe water shortage problem that may affect the sustainable development and hinders the state plans for industrial and agricultural activity. It emphasizes the need to have balance between population growth and the water capacity of the hydrological basins to satisfy the water demand.

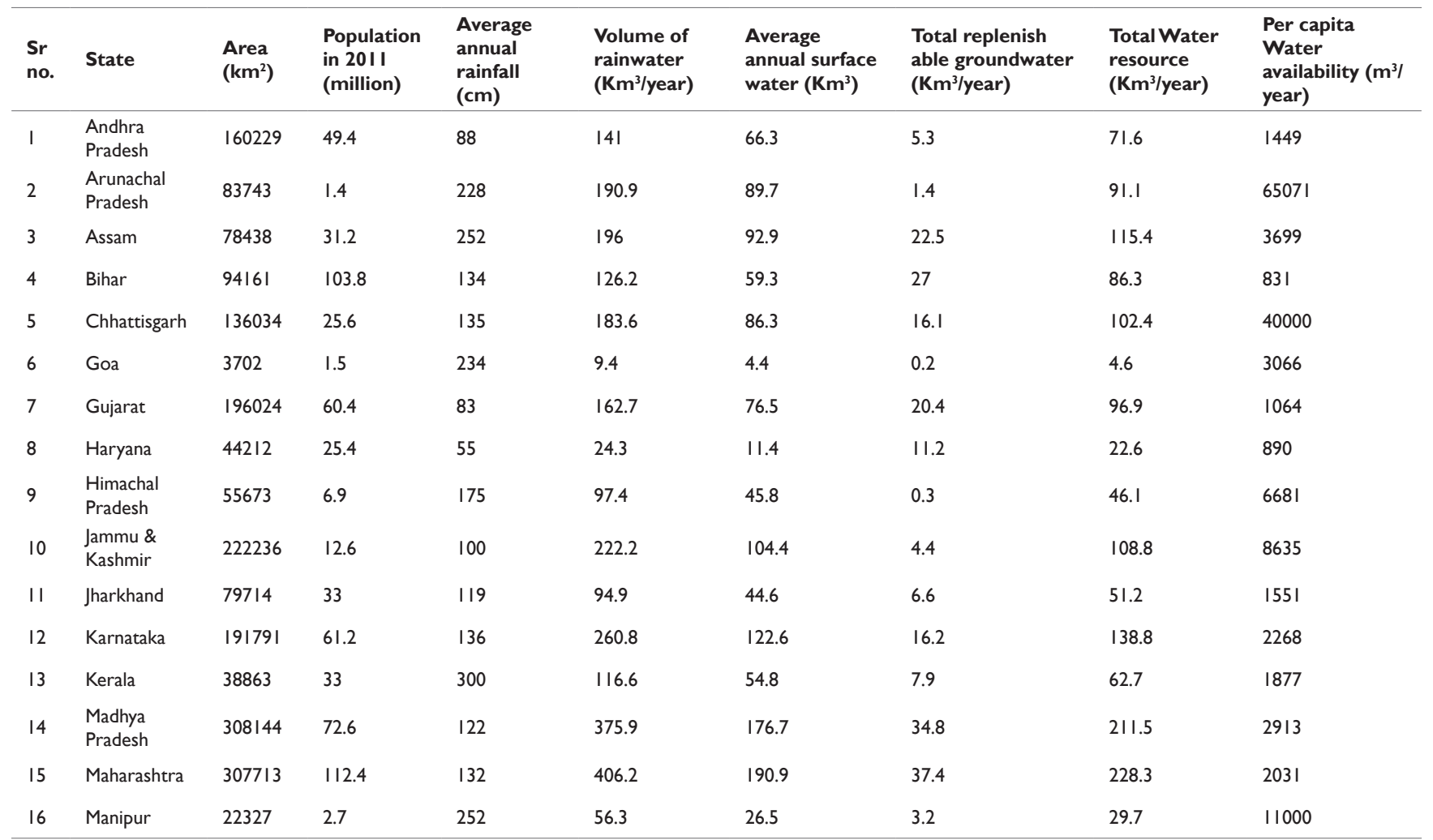


Table Continues...

\begin{tabular}{|c|c|c|c|c|c|c|c|c|c|}
\hline $\begin{array}{l}\text { Sr } \\
\text { no. }\end{array}$ & State & $\begin{array}{l}\text { Area } \\
\left(\mathbf{k m}^{2}\right)\end{array}$ & $\begin{array}{l}\text { Population } \\
\text { in } 201 \mathrm{I} \\
\text { (million) }\end{array}$ & $\begin{array}{l}\text { Average } \\
\text { annual } \\
\text { rainfall } \\
(\mathrm{cm})\end{array}$ & $\begin{array}{l}\text { Volume of } \\
\text { rainwater } \\
\left(\mathrm{Km}^{3} / \text { year }\right)\end{array}$ & $\begin{array}{l}\text { Average } \\
\text { annual surface } \\
\text { water }\left(\mathrm{Km}^{3}\right)\end{array}$ & $\begin{array}{l}\text { Total replenish } \\
\text { able groundwater } \\
\left(\mathrm{Km}^{3} / \text { year }\right)\end{array}$ & $\begin{array}{l}\text { Total Water } \\
\text { resource } \\
\left(\mathrm{Km}^{3} / \text { year) }\right.\end{array}$ & $\begin{array}{l}\text { Per capita } \\
\text { Water } \\
\text { availability }\left(\mathrm{m}^{3}\right) \\
\text { year })\end{array}$ \\
\hline 18 & Mizoram & 21081 & 1.1 & 283 & 59 & 28.1 & - & 28.1 & 25545 \\
\hline 19 & Nagaland & 16579 & 2 & 283 & 46.9 & 22.1 & 0.7 & 22.8 & 11400 \\
\hline 20 & Orissa & 155707 & 42 & 149 & 232 & 109.1 & 20.1 & 129.2 & 3076 \\
\hline 21 & Punjab & 50362 & 27.7 & 63 & 31.7 & 14.9 & 18.2 & 33.1 & 1195 \\
\hline 22 & Rajasthan & 342239 & 68.6 & 59 & 201.9 & 94.9 & 12.6 & 107.5 & 1567 \\
\hline 23 & Sikkim & 7096 & 0.6 & 274 & 19.5 & 9.2 & - & 9.2 & 15333 \\
\hline 24 & Tamil Nadu & 130058 & 72.2 & 101 & 131.4 & 61.8 & 26.4 & 88.2 & 1222 \\
\hline 25 & Telangana & 114840 & 35.1 & 93 & 106.8 & 50.2 & 3.8 & 54 & 1530 \\
\hline 26 & Tripura & 10491 & 3.7 & 252 & 26.4 & 12.4 & 0.7 & 13.1 & 3540 \\
\hline 27 & Uttarakhand & 53483 & 10.2 & 103 & 55.1 & 25.9 & 28.4 & 54.3 & 5234 \\
\hline 28 & $\begin{array}{l}\text { Uttar } \\
\text { Pradesh }\end{array}$ & 238566 & 199.3 & 99 & 236.2 & 110 & 82.6 & 192.6 & 966 \\
\hline 29 & West Bengal & 88752 & 91.4 & 165 & 146.5 & 68.9 & 23.1 & 92 & 1007 \\
\hline- & All India & 3287263 & 1210 & 117 & 4000 & 1869 & 432 & 2301 & 1902 \\
\hline
\end{tabular}

Note:The Government of India has divided the Jammu \& Kashmir state into two Union territories, Jammu \& Kashmir and Ladakh.

\section{Water use in India}

At present water use in India is around $670 \mathrm{~km}^{3} /$ year for the five major sectors namely, domestic, agriculture, industry, hydropower generation and ecosystem conservation ${ }^{2}$ that is some 30 per cent of the annual available fresh water of $2301 \mathrm{~km}^{3} /$ year.

\section{Domestic water use}

The per capita domestic water requirement varies according to geographical location, climatic conditions and the living conditions of the people. According to ${ }^{14}$ each person under normal conditions in an Indian city needs around 135litres of water a day to meet their basic needs for drinking, cooking, cleaning, washing and sanitation. Developed countries like USA, use about 340litres/day/person. The breakup of 135litres is shown in Table 6. Thus the total domestic water demand therefore, is the total population multiplied by 135 litres/day. The total water demand for a population of 1210million in India is estimated at about $60 \mathrm{~km}^{3}$ per year. Apparently, the domestic sector consumes about 10per cent of the total water consumption in India. Ensuring safe drinking water supplies to the entire population has been one of the main focus areas of the Government efforts in the water resources development. The national water policy adopted in 1987 gave top priority to drinking water in allocation of water for various uses. $^{9}$

Table 6 Average domestic water consumption (litres/day/person) in an Indian city ${ }^{14}$

\begin{tabular}{lllllllll}
\hline $\begin{array}{l}\text { Domestic } \\
\text { Water use }\end{array}$ & Drinking & Cooking & bathing & $\begin{array}{l}\text { Washing } \\
\text { clothes }\end{array}$ & $\begin{array}{l}\text { Washing } \\
\text { utensils }\end{array}$ & $\begin{array}{l}\text { Washing } \\
\text { houses }\end{array}$ & Sanitation & Total \\
Consumption & 5 & 5 & 55 & 20 & 10 & 10 & 30 & 135 \\
\hline
\end{tabular}

\section{Industrial water use}

In India, industrial production is concentrated in urban areas, but small-scale industries located in rural areas are spread all over the country. Therefore, the quantity of water required varies considerable with the nature of the urban area. The water use in the industrial sector is about $37 \mathrm{~km}^{3}$, which accounts for 6 per cent of overall water use in India. A large amount of water is required in the manufacturing industry and food processing units.

\section{Water use in agriculture}

Agriculture is still the mainstay of India's economy. The total cultivated area is about $1840000 \mathrm{~km}^{2},{ }^{3}$ which represents about 56 per cent of the total area of the country. ${ }^{3}$ Therefore, agriculture is the largest consumer of water, accounting for some 80 per cent $\left(543 \mathrm{~km}^{3}\right)$ of India's fresh water use. Apart from sunshine and temperature every crop requires a certain amount of water after a certain fixed interval throughout the period of its growth. If the natural rain is adequate and timely so as to satisfy both these requirements then no irrigation water is required for raising that crop. In England, for example, the natural rainfall satisfies both these requirements for practically all crops and therefore irrigation is not significantly needed in England. But in tropical countries like India, the natural rainfall is either insufficient or the water does not fall over fixed intervals of time as required by the crops. Therefore, water has to be provided on to the fields artificially from outside sources by irrigation methods. A detailed account of water requirement by various crops is out of scope of this paper.

\section{Water use for hydropower generation}

Water is an important source of input for the hydropower generation. Hydropower is generated by running the turbine blades by the energy of the flowing water and thus producing electricity from the generator coupled to the turbines. Production of electric power by using the energy of the flowing water is an excellent use of water as no water is consumed in it. Only a certain minimum head is 
required which is dissipated in producing power. In order to ensure the continuous production of hydropower, it is essential to store water to a certain height and then let a discharge flow through the turbines. The construction of a dam reservoir is therefore needed for the generation of the power. In general, hydropower potential in many developing countries is still much under- developed while these countries possess $50 \%$ of the world's hydropower resources, they have exploited only $10 \%$ of their potential. India has vast hydropower potential totaling to about 84 thousand MW at 60 percent load factor. ${ }^{3}$ As against this the hydropower generation capacity which was about $508 \mathrm{MW}$ at the time of independence has now increased to about 44.5thousand MW on account of construction of a number of hydroelectric projects in the country during the last 60years. Industrial and hydropower generation sectors consume about 9percent of the total water consumption in India.

\section{Water conservation and construction of dams in India}

Most of the annual rainfall in India occurs during the 4 months of the southwest monsoon season from June to September, but the availability of water is needed sustainably throughout the year as also to irrigate India's winter crops. This is the reason that dams are built for storing water for its use throughout the year. The main principle guiding the water conservation in India has been to ensure adequate supplies of water for various uses as described in the previous section. There used to be as low as 256storage dams in the country at the time of India's independence in 1947 with a total storage capacity of about $12 \mathrm{~km}^{3}$. After independence, India began constructing a large number of dams which have now risen to $3634 \mathrm{dams}^{15}$ and store $254 \mathrm{~km}^{3}$ water giving per capita an average of $210 \mathrm{~m}^{3}$ of water. Water conservation per person in other countries is: the USA $\left(6000 \mathrm{~m}^{3}\right)$, Australia $\left(5000 \mathrm{~m}^{3}\right)$, China $\left(2500 \mathrm{~m}^{3}\right)$, Spain $\left(1500 \mathrm{~m}^{3}\right)$ and Pakistan $\left(100 \mathrm{~m}^{3}\right)$. The total annual surface water runoff of India is of the order of $1869 \mathrm{~km}^{3}$. However it is estimated that of this surface water only about $690 \mathrm{~km}^{3}$ can actually be stored because of limitations of the most technically attractive sites, climate and soil conditions. While the situation has improved from 250 dams in 1947 but there is a great potential for the construction of more dams for storing monsoon waters. It is mentioned that the construction of large dams has slowed in more developed countries due to environmental disruption, displacement of population etc. However, the construction of large dam projects continues in Turkey, China and India. A number of dams are under construction and at planning stage to further enhance the conservation of water in India.

\section{Water quality in relation to health}

Water quality affects not only the development and utilization of water resources, but also the environment and human health. From the quality point of view the physical features, chemical characteristics and pollution of water are evaluated. Hydrochemistry is one of the characteristics of natural water, which is a complex solution of various chemical elements. About 98 per cent of the total content of ions in natural water is mainly ions of $\mathrm{Ca}, \mathrm{Mg}, \mathrm{Na}, \mathrm{K}, \mathrm{Cl}, \mathrm{SO}_{4}, \mathrm{HCO}_{3}$ and $\mathrm{CO}_{3}$. The standard of water quality therefore, varies considerably according to the intended water use. The drinking water must be colorless, odorless and tasteless. It should be free from suspended matter and should not contain excess of dissolved inorganic chemical elements. Harmful bacteria and radio-activity must be absent. The permissible limits of various chemical elements which are accepted in India for drinking water use ${ }^{16,17}$ are given in Table 7 When these water standards are not fully ensured, the water may not be 100per cent fit for drinking and may be termed as polluted water. The polluted water may sometimes cause many diseases such as typhoid fever, dysentery, gastroenteritis, cholera, Jaundice etc. depending upon the type and extent of pollution. These diseases are known as water borne diseases and are the major cause of deaths globally. If the chloride concentration is more than $250 \mathrm{mg} / 1$ or if hydrogen sulfide $\left(\mathrm{H}_{2} \mathrm{~S}\right)$ is present in water, the water will acquire undesirable tastes and odors. If the sulfate concentration is more than $250 \mathrm{mg} / 1$, a laxative effect is produced on human body. Lead and Barium salts are toxic and only very low concentration is permitted. Similarly, arsenic, and selenium are poisonous and very low concentrations of these salts can be tolerated by human system. High quantities of copper are likely to affect our lungs and respiratory system.

Table 7 Water quality standards for drinking water ${ }^{16,17}$

\begin{tabular}{|c|c|c|c|c|c|}
\hline No. & Parameter & Permissible limits in $\mathrm{mg} / \mathrm{l}$ & No. & Parameter & Permissible limits (mg/l) \\
\hline I & $\mathrm{pH}$ & $6.5-8.5$ & 15 & Nitrate $\left(\mathrm{No}_{3}\right)$ & 45 \\
\hline 2 & Total dissolved solids & 500 & 16 & Phenolic compound & 0.001 \\
\hline 3 & Aluminum (Al) & 0.03 & 17 & Selenium (Se) & 0.01 \\
\hline 4 & Ammonia & 0.5 & 18 & Sulphate $\left(\mathrm{So}_{4}\right)$ & \\
\hline 5 & Boron (B) & 0.5 & 19 & Total hardness (as $\mathrm{CaCo}_{3}$ ) & 0.1 \\
\hline 6 & Barium & 0.7 & 20 & Zinc $(Z n)$ & 5 \\
\hline 7 & Calcium (Ca & 75 & 21 & Cadmium & 0.003 \\
\hline 8 & Chloride (Cl) & 250 & 22 & Cyanide (CN) & 0.05 \\
\hline 9 & Copper (Cu) & 0.05 & 23 & Lead $(\mathrm{Pb})$ & 0.01 \\
\hline 10 & Fluoride (F) & 1.0 & 24 & Mercury (Hg) & 0.01 \\
\hline II & Iron (Fe) & 0.3 & 25 & Arsenic (As) & 0.01 \\
\hline 12 & Magnesium (Mg) & 30 & 26 & Nickel (Ni) & 0.02 \\
\hline 13 & Manganese (Mn) & 0.1 & 27 & Chromium (Cr) & 0.05 \\
\hline 14 & Mineral oil & 0.5 & 28 & B.O.D. & Nil \\
\hline
\end{tabular}




\section{Summary and conclusion}

In conclusion, it can be said that the southwest monsoon that brings water over India is a blessing: it needs to be managed well to temper water shortage situations. India receives every year an average annual rainfall of $117 \mathrm{~cm}$ - some $4000 \mathrm{~km}^{3}$ of rainwater which is more in number than elsewhere in the world. Of the $4000 \mathrm{~km}^{3}$, the amount of water available for use is $2301 \mathrm{~km}^{3}$ which include $1869 \mathrm{~km}^{3}$ of mean annual runoff in its rivers and $432 \mathrm{~km}^{3}$ of groundwater recharge. The available amount of water in India is enough because at present water use in India is around $670 \mathrm{~km}^{3}$ (only 30 per cent of $2301 \mathrm{~km}^{3}$ ). Therefore, India is not a water deficit country. Nevertheless, of the 28states, four states namely, Haryana, Uttar Pradesh, Bihar and West Bengal are characterized as water scarce states because their per capita water availability is less than $1000 \mathrm{~m}^{3} /$ year. The authorities of these states need to make sustainable efforts to put a curb on water scarcity and to achieve water security. It is a fact that a lot of water gets wasted because of our notions of Indian hospitality which dictates that all visitors must be greeted with unasked for glassful of water. Often the guests will take a sip or two and the rest is thrown away. Moreover, it is said of persons who are spendthrifts that they spend money like water. That description might soon have to be changed so that such people are said to spend water as though it were money.

\section{Acknowledgments}

None.

\section{Conflicts of interest}

The author declares that there is no conflict of interest.

\section{Funding}

None.

\section{References}

1. Rakhecha PR. Assessment of water resources and seasonal prediction of rainfall in India. Proc of IAHS on water resources assessment and seasonal prediction held at Koblenz, Germany, PIAHS. 2016;374:151-157.

2. Rakesh Kumar, RD Singh, Sharma KD. Water Resources of India. Current Science. 2005;89(4):794-811.
3. Ministry of Information \& Broadcasting (MI \& B). A reference Manual MI \& B publ Government of India, New Delhi. 2012.

4. Rakhecha PR. Hydrometeorological studies for the development of water resources of India. $J$ of Water Resource and Hydraulic Engineering. 2015;4(2):151-159.

5. Dhar ON, Rakhecha PR. A review of hydrometeorological studies of Indian rainfall. Proc Second World Congress on Water Resources organized by International Water Resources Association, held at New Delhi. 1975;3:449-462.

6. Dhar ON, Rakhecha PR. A review of rainfall relationship based upon Indian data. Water Resources Journal ESCAP, Bangkok. 1979;16-25.

7. Parthasarathy B, Munot AA, Kothawale DR. All India monthly and seasonal rainfall series: 1871-1993. Theoretical \& Applied Climatology. 1994;49:217-224

8. Rao KL. India's Water Wealth. Orient Longman, New Delhi. 1975.

9. Ministry of Water Resources. National Water Policy. Government of India, New Delhi. 2002. 9. p.

10. Rakhecha PR, Singh VP. Applied Hydrometeorology. Capital Publishing Company, New Delhi. 2009. 384 p.

11. Central Ground Water Board (CGWB). Bhu Jal News (Special issue on groundwater statistics). J CGWB, Ministry of Water Resources Publ. Government of India. 1991;6:1-162.

12. Chadha DK. Development of groundwater resources of India. A overview, groundwater modeling \& management. Capital Publishing Company, New Delh. 2006.

13. India Meteorological Department (IMD). Monthly and annual averages of rainfall and of rainy days. Memoirs of IMD. 1962;31:65-208.

14. Garg SK. Hydrology and Water Resources Engineering. Khanna Publishers, Delhi. 1984;523 p.

15. Central Water Commission (CWC). National Register of large dams. CWC Dam Safety Organization, New Delhi. 1990. 102 p.

16. Bureau of Indian Standards (BIS). Drinking water specification. IS 10500 , New Delhi. 1992.

17. World Health Organisation (WHO). Guidelines for drinking water quality. Recommendations. WHO, Geneva. 1984. 130 p. 